\title{
Bioethanol Production from Wastewater of Brown Sugar Home Industry in Kediri via Enzymatic Hydrolysis and Fermentation
}

\author{
Soeprijanto Soeprijanto ${ }^{1 *}$, Afan $\operatorname{Hamzah}^{1}$, Nabila Fara Anindya ${ }^{1}$, Putri Selly Mudyawati ${ }^{1}$
}

\begin{abstract}
Bioethanol is ethanol whose main ingredients are from plants and generally use in a pharmaceutical process. Therefore, Indonesia still needs a more effective source of bioethanol as fuel. Bioethanol production from vegetable waste is a realistic solution, one example is waste from the brown sugar home industry. The purpose of this research is to innovate the production of bioethanol by utilizing sugarcane waste in a brown sugar industry home using the Enzyme Hydrolysis and Fermentation. The results showed that the maximum sugar content was achieved by using a concentration ratio of sugarcane juice: water $=1: 0$ with an enzyme hydrolysis process of $196.08 \mathrm{~g} / \mathrm{L}$. The maximum bioethanol content after fermentation was $18.6 \%$ and reducing sugar of $10.98 \mathrm{~g} / \mathrm{L}$ was achieved by using $10 \%$ of saccharomyces cerevisiae at a concentration of sugar cane juice: water ratio $=1: 1$. The maximum bioethanol content after the fermentation process was $12.96 \%$ and the reducing sugar was $27.78 \mathrm{~g} / \mathrm{L}$ was achieved using $10 \%$ fermented cassava yeast at a concentration ratio of sugarcane juice: water = 1:1.
\end{abstract}

Keywords_Brown sugar, Hydrolysis, Fermentation, Bioethanol, Wastewater

\section{INTRODUCTION}

A ccording to data, currently, the world's energy sources are still dominated by non-renewable natural resources including oil, coal, and natural gas, namely: about $80.1 \%$, where each use is refined petroleum by $35.03 \%$, coal as much as $24.59 \%$, and natural gas around $2044 \%$ [1]

The increase in the price of fossil-based fuel in 2005. which had touched the figure of more than 70 us dollars per year barrel becomes an important momentum for the development of domestic biofuel. One of the reasons for the increase in fuel prices is the depletion of its reserves [2].

Today, the government has issued a Presidential Regulation of the Republic of Indonesia Number 5 of 2006 concerning National Energy Policy to develop alternative energy sources as a substitute for fuel (Prihandana, 2007). Biobased fuels can also reduce environmental pollution, make them more environmentally friendly [3].

The wastewater contained in the brown sugar factory will be used is sap sugarcane waste, sap waste is one of the waste products resulting from the processing of sugar cane which can no longer be crystallized and still containing sugar and non-sugar (organic) materials [4].

Therefore, further processing is needed to reduce the amount of sap waste and increase the use-value of this waste.

TABLE 1.

ChEMICAL COMPOSITION OF SUGARCANE WASTE

\begin{tabular}{cc}
\hline \hline Chemical Composition & Amount (\%) \\
\hline Water & 10.32 \\
Sucrose & 40 \\
Glucose & 5.7 \\
Fructose & 9 \\
Protein & 4 \\
\hline \hline
\end{tabular}

1 Department of Industrial Chemical Engineering, Faculty of Vocational Studies, Institut Teknologi Sepuluh Nopember, Kampus ITS, Sukolilo, Surabaya, 60111. Email: soeprijanto@chem-eng.its.ac.id
According to Irawan (2015), sugarcane juice is a liquid juice obtained from sugarcane milling that has a greenishbrown color. Sugarcane is a disaccharide, the sugar can be made from the combination of two simple sugars, namely glucose and fructose (a monosaccharide). Apart from the sucrose in the stem sugarcane contains other substances [5]. The manufacture of bioethanol containing sucrose uses several stages, namely pretreatment, hydrolysis, fermentation, and distillation.

The hydrolysis temperature is related to the rate of reaction. The higher the hydrolysis temperature, the hydrolysis will go faster. This is due to the constant reaction rate increases with increasing temperature surgery [6].

The factors that affect the fermentation process are [7] The type of microbe used must be able to grow rapidly in a suitable substrate and the organism must be able to organize and break down complex components into simpler substances. Optimum $\mathrm{pH} 4-4.5$, Temperature, the optimal temperature ranges between $25-30{ }^{\circ} \mathrm{C}$, the temperature during fermentation needs to get attention because in addition to temperature has an effect which directly affects the growth of yeast to affect the composition of the final product and oxygen

These experiments aimed to study the effect of the amount of baker's yeast and tape yeast on the production of ethanol in the fermentation; and the effect of the sugar content of sap sugarcane wastewater on ethanol production

\section{METHOD}

\section{A. Material}

Sugarcane wastewater was obtained from home industries in Kediri; methylene blue, Fehling A, and Fehling B, were used to analyze reducing sugar content in a sample, purchased at a Chemical Store in Surabaya; urea and NPK, used as nutrients in fermentation, were supported from Industrial Biotechnology Laboratory, 
Department of Industrial Chemical Engineering, ITS; baker's yeast and tape yeast were purchased at Food Store.

\section{B. Experimental Setup}

Brown sugar waste, sap sugarcane, was filtered using a vacuum filter until the sap was clean enough from residue. Then it was mixed with distilled water with ratios of $1: 0$, $1: 1$, and $1: 2$, respectively.

\section{Liquefaction Process}

The filtered sample was then enzymatically hydrolyzed via liquefaction process, added with $5 \mathrm{~mL}$ of an $\alpha$-amylase enzyme, and heating to a hot plate stirrer at $90^{\circ} \mathrm{C}$ for $2 \mathrm{~h}$. The sample was analyzed every $30 \mathrm{~min}$ up to $2 \mathrm{~h}$.

$$
\mathrm{C}_{12} \mathrm{H}_{22} \mathrm{O}_{22}+\mathrm{H}_{2} \mathrm{O}+\text { E. } \alpha \text {-amylase } \longrightarrow \mathrm{C}_{6} \mathrm{H}_{12} \mathrm{O}_{6} \ldots . .(1)
$$

\section{Saccharification Process}

After liquefaction, the process was continued to the Saccharification process; the sample was then added with Glucoamylase enzyme as much as $5 \mathrm{~mL}$. The process was carried by heating on a hot plate stirrer at $65^{\circ} \mathrm{C}$ for $4 \mathrm{~h}$. Afterward, the sugar content in a sample was analyzed every $30 \mathrm{~min}$ up to $4 \mathrm{~h}$.

$$
\mathrm{C}_{6} \mathrm{H}_{12} \mathrm{O}_{6}+\mathrm{H}_{2} \mathrm{O}+\text { E. Glucoamylase } \longrightarrow \mathrm{C}_{6} \mathrm{H}_{12} \mathrm{O}_{6} \ldots
$$

\section{E. Fermentation of Bioethanol}

The fermentation process is intended to change reducing sugar into ethanol using saccharomyces cerevisiae and fermented cassava yeast. Various ratios of saccharomyces cerevisiae and fermented cassava yeast $=5,10$, and $15(\%$ weight); and nutrients (urea and NPK) : sugar $=2: 3(\%$ weight), respectively, were used in the fermentation. Products of fermentation are ethanol and carbon, Fermentation was carried out for Approx.

$$
\mathrm{C}_{6} \mathrm{H}_{12} \mathrm{O}_{6} \longrightarrow 2 \mathrm{C}_{2} \mathrm{H}_{5} \mathrm{OH}+2 \mathrm{CO}_{2} \ldots \text { (3) }
$$

\section{F. $\quad$ Calculation of reducing sugar content}

Prepare a solution of Fehling A and Fehling B each as much as $10 \mathrm{~mL}$ Prepare Methylene Blue indicator with concentration $10 \mathrm{~g} / \mathrm{L}$. Prepare a sugar solution to be analyzed in burettes. Enter the Fehling A and Fehling B solutions as much as $10 \mathrm{~mL}$ into Erlenmeyer, then add methylene blue indicator solution. Heating the mixed solution until it boils then titrate the solution in Erlenmeyer with sugar solution in the burette and measure. The volume of solution used for the titration.

Calculation reducing sugar content :

Where :

$$
\mathrm{Cspl}=\frac{\text { Cstd } \mathrm{x} \text { Vstd }}{\mathrm{Vspl}}(\mathrm{g} / \mathrm{L})
$$

$\mathrm{C}_{\mathrm{spl}}=$ sample concentration, $\mathrm{g} / \mathrm{L}$

$\mathrm{V}_{\mathrm{spl}}=$ sample volume, $\mathrm{mL}$

$\mathrm{C}_{\text {std }}=$ standard concentration, $\mathrm{g} / \mathrm{L}$

$\mathrm{V}_{\text {std }}=$ standard volume, $\mathrm{mL}$

\section{G. Analysis of Ethanol}

Analysis of ethanol content using the gas chromatography method (GC). A sample of ethanol solution as much as $5 \mathrm{~mL}$ of the fermented product was centrifuged at a speed of $15000 \mathrm{rpm}$ for $20 \mathrm{~min}$, then $1 \mu \mathrm{l}$ of the sample was injected into GC Shimadzu FID, under the following conditions injection at temperature $125^{\circ} \mathrm{C}$, isothermal oven temperature $55^{\circ} \mathrm{C}$ and FID detector $150^{\circ} \mathrm{C}$.

\section{RESUlTS AND DisCUSSION}

The hydrolysis process was carried out with the use of $\alpha$ amylase enzymes at the liquefaction process and glucoamylase enzymes at the saccharification process. The $\alpha$-amylase enzyme was used in the hydrolysis of $\alpha-1,4$ glycosidic amylose starch to produce glucose, and the glucoamylase enzyme was used in the hydrolysis process aim to increase glucose levels in sugarcane. The raw materials were hydrolyzed using $5 \mathrm{~mL}$ of $\alpha$-amylase and glucoamylase enzymes. This study was conducted using ratio of concentration of sugarcane wastewater : water = $1: 0,1: 1,1: 2$; various percentage of saccharomyces cerevisiae $(5 \%, 10 \%, 15 \%)$; and various percentage of fermented cassava yeast $(5 \%, 10 \%, 15 \%)$.

\section{A. Effect of substrate ratio on Reducing Sugar production $s$}

The liquefaction process was conducted with the use of a $5 \mathrm{~mL} \alpha$-amylase enzyme. Figure 3.1 shows that the reducing sugar production increased for $2 \mathrm{~h}$, then was constant up to $120 \mathrm{~min}$. In each parameter of ratios depicted that the highest reducing sugar production after hydrolyzing obtained was $58.82 \mathrm{~g} / 1$ at a ratio of 1:0 for 30 min. This is similar to the other authors, they stated that the production of reducing sugars increased with increasing the concentration of the $\alpha$-amylase enzyme [8].

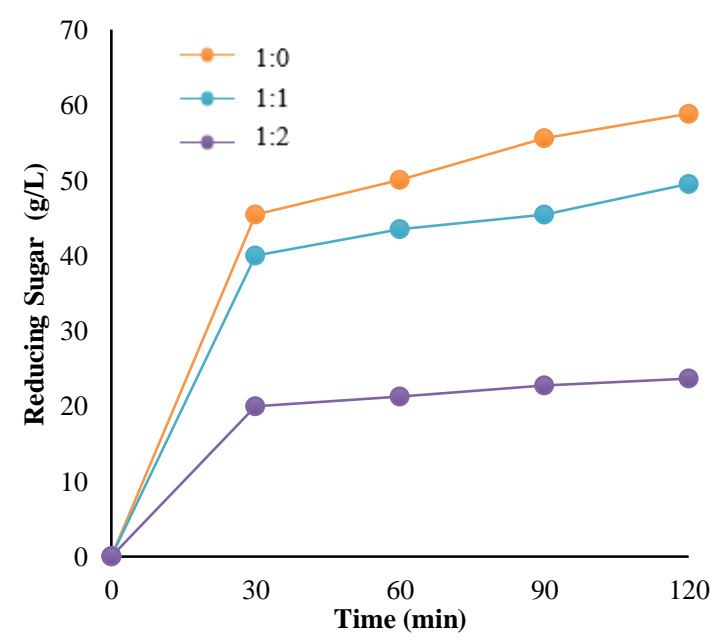

Figure 1 Effect of Ratio Sugarcane: Water on Reducing Sugar production in Liquefaction.

The saccharification process was conducted with the use of a $5 \mathrm{~mL}$ Glucoamylase enzyme. Figure 3.2 shows the effect of Sugarcane: Water ratio on the production of the reducing sugar in the saccharification. In the hydrolysis, the results of reducing sugar increased with time for $4 \mathrm{~h}$. The sugar obtained was analyzed every $30 \mathrm{~min}$. The results indicated that the largest reducing sugar concentration in the sap sugarcane wastewater was found to be $198.08 \mathrm{~g} / \mathrm{L}$ 
with a volume ratio of 1:0 using enzymatic hydrolysis. This is consistent with literature that explains that the greater the concentration of the addition of enzymes, the greater the activity of enzymes in the media so that more sucrose is converted into reducing sugars [9].

This is following the literature, the longer the hydrolysis process, the more complete the breakdown of sucrose into glucose so that maximum glucose levels are obtained [10].

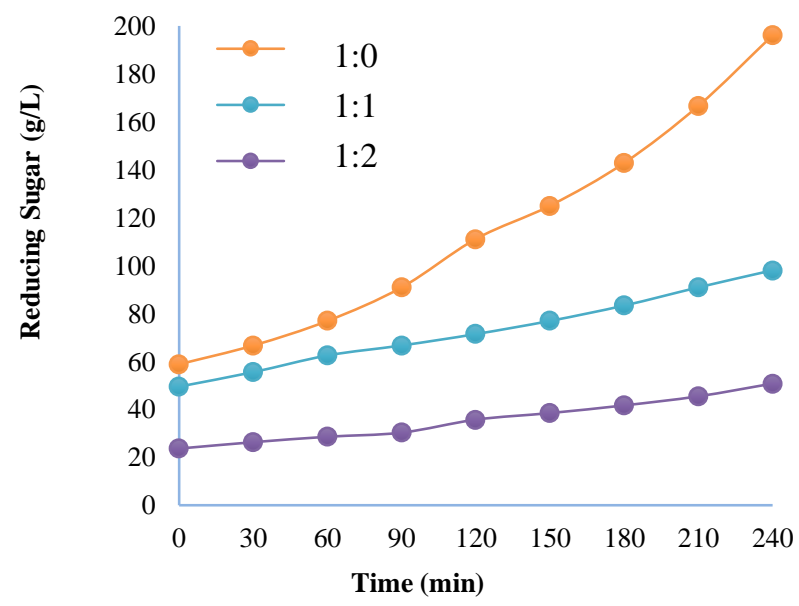

Figure 2 Effect of Ratio Sugarcane: Water in Reducing Sugar on Saccharification Process

\section{B. Ethanol Production in the Fermentation}

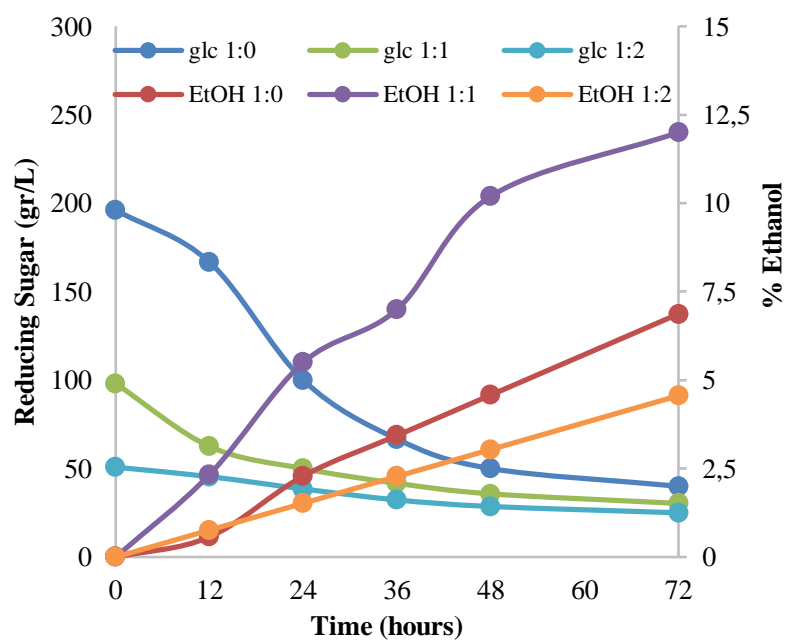

Figure 3 The Relationship between Ethanol Content, Reducing Sugar Content, and Time on 5\% Saccharomyces Cerevisiae with Sugarcane: Water Ratio $=1: 0,1: 1$, and $1: 2$

The fermentation process was conducted with the use of saccharomyces cerevisiae and fermented cassava yeast. Figure 3.3 shows a correlation between ethanol and reducing sugar used in this fermentation. The results depicted that the production of ethanol was influenced by the initial reducing sugar. The ethanol production increased with increasing the use of initial reducing sugar. It was found that ethanol content obtained was $12 \%$ with the use of $5 \%$ saccharomyces cerevisiae, a ratio of $1: 1$ substrate. The sugar supplies increase the rate of bacterial growth, bacteria divide rapidly, besides that there is no dead yeast so the ethanol content produced is also high and reaches that maximum point. This means that the sugar concentration is the optimal condition for the catabolic activity of saccharomyces cerevisiae.

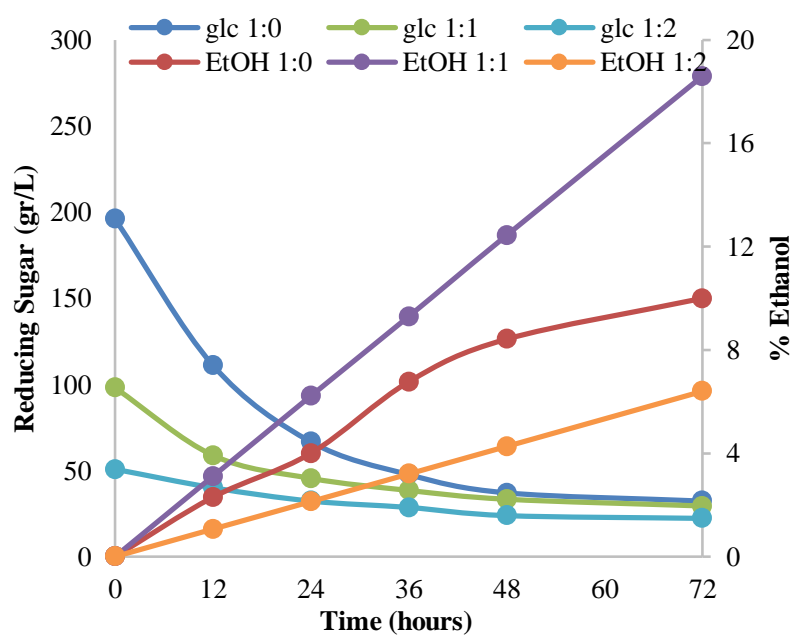

Figure 4 The Relationship between Ethanol Content, Reducing Sugar Content, and Time on $10 \%$ Saccharomyces Cerevisiae with Sugarcane: Water Ratio $=1: 0,1: 1$, and $1: 2$

Figure 4 shows the correlation between ethanol and reducing sugars used in this fermentation. The results showed that the production was influenced by the initial reducing sugar. Ethanol production increased with the utilization of the initial reducing sugar. It was found that the ethanol content obtained was $18.6 \%$ with the use of $10 \%$ saccharomyces cerevisiae, with a substrate ratio of $1: 1$. The low concentrations of inoculum resulted in a slow fermentation rate, but could produce higher ethanol because after the cells proliferated, the cells would slowly convert sugar into ethanol.

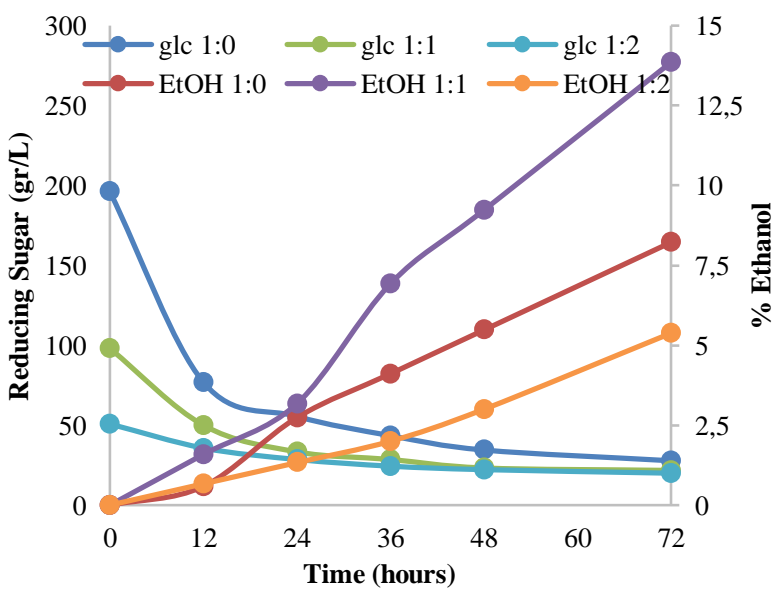

Figure 5 The Relationship between Ethanol Content, Reducing Sugar Content, and Time on 15\% Saccharomyces Cerevisiae with Sugarcane: Water Ratio $=1: 0,1: 1$, and 1:2

Figure 5 shows the correlation between ethanol and reducing sugars used in this fermentation. The results showed that the production was influenced by the initial reducing sugar. Ethanol production increased with the utilization of the initial reducing sugar. It was found that the ethanol content obtained was $13.85 \%$ with the use of $15 \%$ saccharomyces cerevisiae, with a substrate ratio of $1: 1$. The high yeast inoculation caused the weakening process to be faster and decreased cell viability after the growth phase. Growth and metabolism conditions in high 
cell populations are not expected because they interfere with nutrient access, space limitations, and interactions between cells.

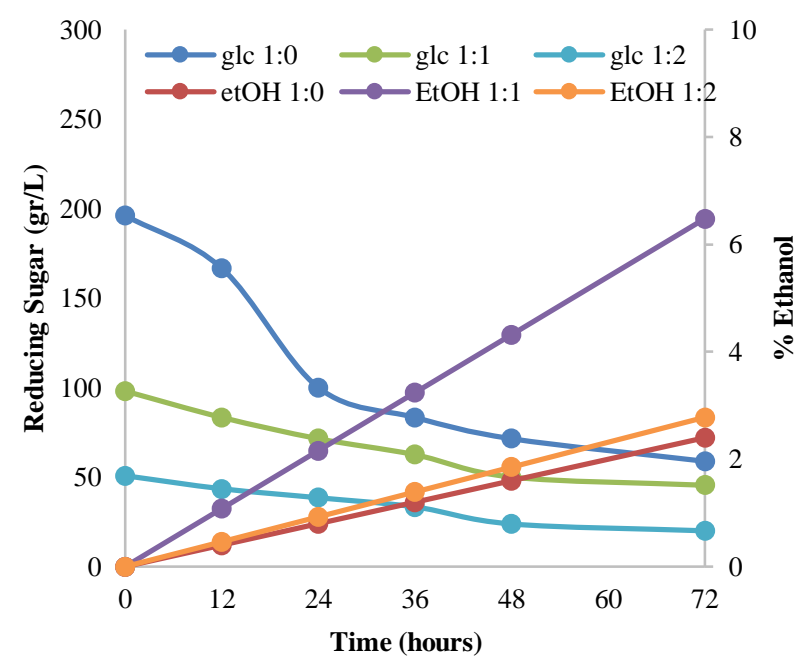

Figure 6 The Relationship between Ethanol Content, Reducing Sugar Content, and Time on 5\% Fermented Cassava Yeast with Sugarcane: Water Ratio $=1: 0,1: 1$, and $1: 2$

Figure 6 shows the correlation between ethanol and reducing sugars used in this fermentation. The results showed that the production was influenced by the initial reducing sugar. Ethanol production increased with the utilization of the initial reducing sugar. It was found that the ethanol content obtained was $6.48 \%$ with the use of 5 fermented cassava yeast, with a substrate ratio of $1: 1$. The high enzyme production causes the process of saccharification of starch to glucose and the conversion of glucose to alcohol is faster.

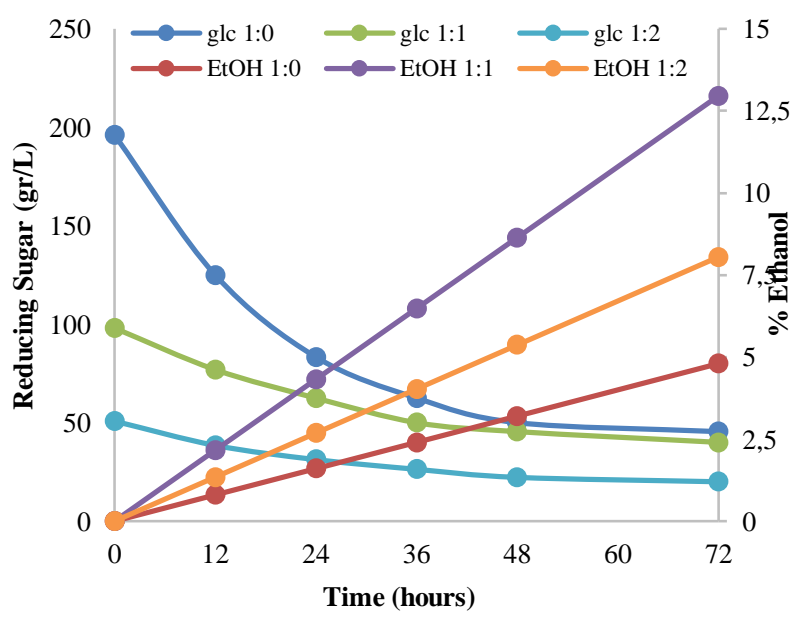

Figure 7 The Relationship between Ethanol Content, Reducing Sugar Content, and Time on 10\% Fermented Cassava Yeast with Sugarcane: Water Ratio $=1: 0,1: 1$, and $1: 2$

Figure 7 shows the correlation between ethanol and reducing sugars used in this fermentation. The results showed that the production was influenced by the initial reducing sugar. Ethanol production increased with the utilization of the initial reducing sugar. It was found that the ethanol content obtained was $12.96 \%$ with the use of $10 \%$ fermented cassava yeast, with a substrate ratio of $1: 1$. the higher the concentration of tape yeast used, the more microbes that produced amylolytic enzymes, so the saccharification process was faster. This is because at that time the activity of the yeast works optimally and the enzymatic activity is not hampered.

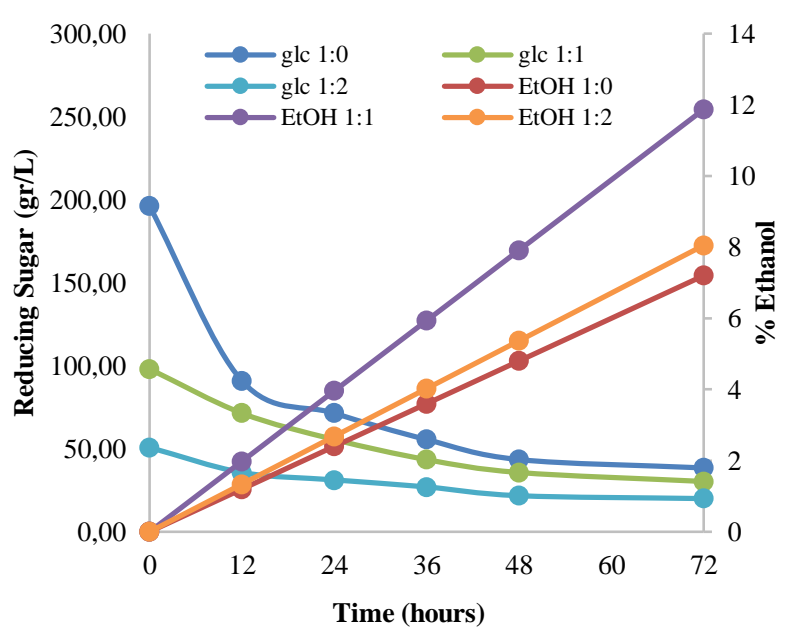

Figure 8 The Relationship between Ethanol Content, Reducing Sugar Content, and Time on $15 \%$ Fermented Cassava Yeast with Sugarcane: Water Ratio $=1: 0,1: 1$, and 1:2

Figure 8 shows the correlation between ethanol and reducing sugars used in this fermentation. The results showed that the production was influenced by the initial reducing sugar. Ethanol production increased with the utilization of the initial reducing sugar. It was found that the ethanol content obtained was $11.87 \%$ with the use of $15 \%$ fermented cassava yeast, with a substrate ratio of $1: 1$. When yeast inoculation was too high, the weakening process became faster and decreased cell viability after the growth phase. Growth and metabolic conditions in high cell populations are not expected because they interfere with nutrient access, space limitations, and interactions between cells.

\section{CONCLUSION}

From the process of making bioethanol from sap sugarcane the brown sugar home industry concluded as follows the maximum reducing sugar content is achieved by using the concentration ratio of sugarcane: water $=1: 0$ with the enzyme hydrolysis process of $196.08 \mathrm{Gr} / \mathrm{L}$. The maximum bioethanol content after the fermentation process by $18.6 \%$ and reducing the sugar by $10.98 \mathrm{Gr} / \mathrm{L}$, achieved by using $10 \%$ saccharomyces cerevisiae at concertation ratio of sugarcane: water $=1: 1$. The maximum bioethanol content after the fermentation process by $12.96 \%$ and reducing the sugar by $27.78 \mathrm{Gr} / \mathrm{L}$ achieved using $10 \%$ fermented cassava yeast at a concentration of sugarcane: water $=1: 1$.

\section{REFERENCES}

[1] Y. Sudiyani, F. Amriani, and S. P. Simanungkalit, Perkembangan Bioetanol G2: Teknologi dan Perspektif. Jakarta: LIPI PRESS, 2019.

[2] Tim Nasional Pengembangan Bahan Bakar Nabati untuk Percepatan Pengurangan Kemiskinan dan Pengangguran, Bahan Bakar Nabati. PT. Penebar Swadaya, Jakarta, 2007.

[3] F. Assegaf, "Prospek Produksi Bioetanol Bonggol Pisang," Semarang : Universitas Jenderal Soedirman, 2009. 
[4] G. Madu, "Molasses/Sugar Blackstrap," Gunung Madu Plantations, 15042016.

[5] R. Kuswurj, "Pemurnian Nira di Pabrik Gula," 08 Febuari 2011.

[6] N. J. Herawati, "Pembuatan Bioetanol dari Pati Ubi Talas (Colocasia L. Schoot) dengan Proses Hidrolisis," vol. Vol. 6 No. 1, pp. 7-17, 2021.

[7] R. Eni, W. Sari, and R. Moeksin, "Pembuatan bioetanol dari air limbah cucian beras menggunakan metode hidrolisis enzimatik dan fermentasi," J. Tek. Kim., vol. 21, no. 1, pp. 14-22, 2015.

[8] S. Soeprijanto, Teknologi Pengembangan Bioetanol dari Biomassa Sorghum, Surabaya: ITS Press, 2013.

[9] S. Soeprijanto, Teknologi Pengembangan Bioetanol dari Biomassa Sorghum, Surabaya: ITS Press, 2013.

[10] C. Devita, W. Pratjojo, and S. M. R. Sedyawati, "Perbandingan metode hidrolisis enzim dan asam dalam pembuatan sirup glukosa ubi jalar ungu," Indones. J. Chem. Sci., vol. 4, no. 1, 2015. 